RADOSŁAW ULISZAK

Uniwersytet Pedagogiczny, Kraków

NINA GRAD

Uniwersytet Jagielloński

\title{
Innowacyjność kluczem rozwoju firmy IBM
}

Dostosowanie się do nowych warunków funkcjonowania przedsiębiorczości powinno odbywać się m.in. poprzez rozwijanie gospodarki opartej na wiedzy i kształtowanie społeczeństwa informacyjnego. Takie założenia zawiera polityka gospodarcza Unii Europejskiej. Podkreśla ona znaczenie kreowania gospodarki opartej na innowacyjności, wiedzy i otwartości na współczesne zmiany (Grad 2007). Gospodarka oparta na wiedzy funkcjonuje kładąc nacisk na „wykorzystanie zasobów wiedzy oraz rozwój technologii umożliwiającej szybki i tani dostęp do informacji, a podstawą jej rozwoju jest zdolność do generowania i dyfuzji innowacji” (Borowiec, Dorocki, Jenner 2009). Umiejętność wykorzystania wiedzy i informacji jest podstawą budowania innowacyjności, czyli zdolności podmiotów i gospodarek do tworzenia i wdrażania innowacji, podejmowania działań pobudzających innowacyjność oraz angażowania niezbędnych zasobów. Szczególnie w okresie globalizacji wdrażanie nowych technologii jest strategicznym czynnikiem przesądzającym o konkurencyjności poszczególnych krajów, dlatego też wzrost innowacyjności odbierany jest jako decydujący kierunek przekształcania się społeczeństw Unii Europejskiej w społeczeństwa informacyjne (Gierańczyk 2009).

Postępujące procesy rozwoju społeczno-gospodarczego prowadzą do kształtowania nowej bazy ekonomicznej, którą tworzy gospodarka oparta na wiedzy (Kukliński 2001). Funkcję motoryczną w tym procesie pełnią duże korporacje międzynarodowe o znacznym kapitale, zarządzane przez wysoko wykwalifikowane grupy menedżerskie. Bardzo często takie przedsiębiorstwa mają własne instytucje naukowe prowadzące badania podstawowe, badawczo-rozwojowe, a także edukacyjne, finansowe i prawne oraz różnorodne oddziały i filie. Spełniają one różne funkcje w złożonych procesach produkcyjnych wielu zakładów, rozmieszczonych w przestrzeni światowej wszystkich kontynentów (Zioło 2009).

„Innowacje stanowią podstawę postępu technicznego i rozwoju przemysłów wysokiej techniki, ale równocześnie obejmują sfery: społeczną, polityczną, duchową, zdrowia, konsumpcji oraz wiedzy. Innowacje we współczesnych warunkach nowego sposobu wytwarzania wiedzy są efektem zbiorowych wysiłków i współdziałania wielu podmiotów. Wymagają systemowego podejścia, które odzwierciedlane jest przez różnego rodzaju systemy innowa- 
cyjne: od systemów innowacyjnych poszczególnych firm, poprzez regionalne systemy innowacyjne, do krajowego systemu innowacyjnego (Bal-Woźniak 2009, s. 45).

Proces rozwoju społeczeństwa informacyjnego w podstawowym stopniu stymulują firmy informatyczne. W rozwoju społeczeństwa informacyjnego niezwykle istotny jest rozwój sektora informatyki, a ogromny wpływ na ten proces wywierają światowe korporacje informatyczne. W zależności od ich potencjału i spełnianych funkcji oddziałują one na układy przestrzenne różnej skali. Szczególne znaczenie w tym względzie mają korporacje ponadnarodowe o dużym potencjale ekonomicznym, jak IBM, Apple czy Microsoft (Kilar 2009). To one przyczyniają się do szybkiego, masowego wprowadzania $\mathrm{w}$ życie innowacyjnych idei i produktów opracowanych bądź to we własnych centrach badawczych, bądź w firmach zakupionych przez korporacje. Jednak wśród 1000 największych korporacji światowych najliczniejszą grupę stanowią obecnie korporacje finansowe (245 firm), następne pod względem liczebności są korporacje zajmujące się projektowaniem i dystrybucją artykułów luksusowych (141), przemysłowe (114), a informatyczne są dopiero na czwartym miejscu (104). Łącznie obejmują one 59,9\% ogólnej liczby korporacji i 56,2\% wartości rynkowej. Pod względem wartości rynkowej także dominują korporacje związane z finansami (24,3\% wartości rynkowej), a kolejne pozycje zajmują korporacje reprezentujące informatykę (10,3\%), artykuły luksusowe i opiekę zdrowotną (Zioło 2006).

Wśród koncernów informatycznych, wyróżniającą się firmą jest IBM (International Business Machines). Celem referatu jest przedstawienie potencjału ekonomicznego firmy IBM oraz wskazanie innowacyjnego charakteru rozwiązań wprowadzonych przez firmę zarówno w zakresie technologicznym jak i szerokiego zakresu usług.

\section{Potencją IBM}

Międzynarodowe korporacje informatyczne biorą udział w nieustannym wyścigu zmierzającym do wyznaczenia kierunku rozwoju w swojej branży. Nie każde przedsiębiorstwo ma jednak możliwość utrzymania się w czołówce rankingów. Decydować mogą o tym nietrafione decyzje o kierunku rozwoju, innowacje wdrożone przez konkurencję jak i sytuacja na rynku. Zmieniające się warunki mikro- i makroekonomiczne, sytuacje na międzynarodowych rynkach finansowych nie pozostają niezauważone w bilansach nawet największych firm. Bardzo istotny jest także sam potencjał ekonomiczny firm, gdyż to dzięki niemu istnieje możliwość ciągłych badań, poszukiwań, nabywania patentów, technologii i pomysłów opracowanych w mniejszych przedsiębiorstwach i wdrażania nowych rozwiązań.

„Podstawową rolę w strukturze korporacji odgrywa kapitał, wyrażony m.in. wartością rynkową korporacji, wartością majątku, wielkością zysku czy wielkością kapitału obrotowego. Wartość kapitału określa pozycję korporacji w gospodarce światowej, krajowej czy regionalnej (Zioło 2009, s. 14).

Firma International Business Machines (IBM) powstała dość dawno jak na firmę informatyczną, bo w 1911 roku. Początkowo zajmowała się różnorodną produkcją: wag, krajalnic do mięsa, czy nośników danych (karty dziurkowane) i maszyn do ich przetwarzania. Te ostatnie stały się z czasem najważniejszą dziedziną działalności korporacji. Kolejnym przełomowym wynalazkiem wykorzystywanym powszechnie do dziś, było wprowadzenie 
na rynek, na przełomie lat 50. i 60. XX w., komputerowych dysków twardych. Rok 1962 zaznaczył się obecnością firmy na rynku usług informatycznych. Wtedy to uruchomiony został pierwszy system rezerwacji i sprzedaży biletów lotniczych. System Sabre, wykonany na potrzeby jednych z największych wówczas linii lotniczych, do dziś jest jednym z trzech najważniejszych tego typu systemów na świecie. Z IBM pochodzi również będący do dziś w użyciu język programowania Fortran. W 1969 roku komputery IBM były wykorzystywane przez NASA w trakcie pierwszej misji człowieka na Księżyc. Wydarzeniem, które trwale zmieniło bieg ludzkiej cywilizacji, było stworzenie (w 1981 roku) pierwszego komputera osobistego - IBM 5150 PC. W następnym roku komputer osobisty został ogłoszony przez tygodnik „Time” „człowiekiem roku” (1982 Man of the Year). Dzięki dalekowzrocznej polityce firmy skrót „IBM PC” stał się na wiele lat synonimem komputera w oczach setek milionów użytkowników na całym świecie.

Innowacyjność, niezależnie od epoki, pozwalała IBM wyprzedzać rzeczywistość. W latach 90. firma, skupiona na rozwoju komputerów, zaczęła dywersyfikować swoją działalność i rozwijać się na nowych obszarach rynku, w szczególności usługach. IBM, który do dziś jest kojarzony tylko jako producent sprzętu komputerowego, od dłuższego już czasu sprofilował swoją działalność na konsulting w branży informatycznej. Firma sprzedała część swojego działu produkcji komputerów (PC) chińskiej firmie Lenovo i skupiła się głównie na oprogramowaniu, które pomaga w zarządzaniu firmą, a nawet całym miastem. IBM dostarcza technologie samorządom, które pretendują do miana miast przyszłości - energooszczędnych i perfekcyjnie zorganizowanych, tak, aby zminimalizować koszty zarządzania skomplikowanymi organizmami miejskimi (jak zminimalizować korki, jak najszybciej zlokalizować i naprawić dziurawy wodociąg czy ugasić pożar).

IBM odpowiada swoim profilem działalności na aktualne potrzeby rynku, dzięki czemu cały czas się rozwija i zajmuje coraz wyższe pozycje w światowych rankingach. W 2010 roku firma odnotowała przychody 99,9 mld USD (w 2009 roku 95,8 mln USD, wzrost o 4,3\%), zysk 14,9 mld USD (w 2009 roku 13,4 mld USD, wzrost o 10,5\%), środki trwałe 113,5 mld USD (w 2009 roku 109 mln USD - wzrost o 4,1\%), liczbę pracowników 426751 (w 2009 roku 399 409). Wyniki finansowe IBM w następnych kwartałach mogą być równie imponujące biorąc pod uwagę ,zakupy” koncernu. Tylko w 2010 roku IBM wykupił 17 firm, m.in. Blade Network Technologies (sieci komputerowe), Initiate Systems (oprogramowanie wymiany danych), Netezza (centra obliczeniowe), Cast Iron Systems (chmury obliczeniowe), Sterling Commerce (systemy e-sprzedaży), Coremetrics (oprogramowanie do analiz rynkowych), BigFix (zarządzanie sieciami), Datacap (automatyzacja przepływu dokumentów), Unica (oprogramowanie do analiz marketingowych), OpenPages (analizy biznesowe), łącznie wydając na ten cel 6 miliardów dolarów (ftp://public.dhe.ibm.com/ annualreport/2010/201). Charakter tych zakupów może świadczyć o obecnych założeniach i charakterze dalszego rozwoju firmy. Z przedstawionych powyżej przykładów wyraźnie widać, że przetwarzanie danych i analizy rynkowe są ważnym polem przyszłych działań IBM.

Przestrzenne zróżnicowanie przychodów wskazuje, że rynki rozwinięte pod względem technologicznym są dla koncernu najważniejsze. IBM postrzegany jest jako korporacja globalna, ale aż 42\% przychodów generowane jest w Ameryce Północnej, 32\% w Europie a 23\% w Azji Południowo-Wschodniej. Pozostałe regiony świata stanowią znikomy udział, choć firma jest na nich obecna. Składowe łącznej wartości przychodu przestawia tab. 1. 
Tab. 1. Przychód IBM według działów w 2009 i 2010 roku (w mln USD)

\begin{tabular}{|l|r|r|}
\hline \multicolumn{1}{|c|}{ Dział } & \multicolumn{1}{c|}{2010} & \multicolumn{1}{c|}{2009} \\
\hline Serwis technologiczny & 38201 & 37347 \\
\hline Serwis biznesowy & 18223 & 17653 \\
\hline Oprogramowanie & 22495 & 21396 \\
\hline System i technologia & 17973 & 16190 \\
\hline Finanse & 2238 & 2302 \\
\hline Inne & 750 & 869 \\
\hline Łącznie & 99879 & 95758 \\
\hline
\end{tabular}

Źródło: opracowanie własne na podstawie rocznego raportu finansowego IBM

Struktura przychodów koncernu w 2010 roku wykazuje dość równomierne udziały głównych obszarów działania firmy. W analizowanych latach prawie $40 \%$ przychodów zapewnił serwis technologiczny, który pozwala dostarczyć rozwiązania informatyczne sprzyjające innowacyjności, obniżeniu kosztów i transformacji organizacji. Usługami w ramach serwisu technologicznego są: bezpieczeństwo w sieci i ochrona prywatności, data center, optymalizacja środowisk użytkowników, outsourcing systemów i aplikacji, usługi serwerowe w zakresie pamięci masowych, serwisu i wsparcia technicznego, zintegrowane usługi sieciowo-komunikacyjne. Serwis biznesowy to ponad 18\% przychodów, a pomaga on w tworzeniu i implementacji kluczowych procesów strategicznych i inicjatyw technologicznych. Oprogramowanie (22,5\%) to przede wszystkim cztery działy: IBM Information Management (bazy danych, hurtownie danych, narzędzia business intelligence oraz zarządzanie treścią), IBM WebSphere (oprogramowanie warstwy pośredniej do integracji aplikacji i automatyzacji procesów biznesowych), IBM Lotus (praca grupowa, zintegrowana komunikacja oraz budowanie dynamicznych portali korporacyjnych), IBM Tivoli (zarządzanie pamięciami masowymi, infrastrukturą IT oraz bezpieczeństwem).

Jednym z ciekawszych zestawień pokazujących rynek informatyczny jest Ranking Business Week'a. Przedstawia on 100 największych firm informatycznych. Jeżeli chodzi o wartość sprzedaży w 2008 roku IBM był na czwartym miejscu, z wartością 100,8 mld USD. Pierwsze miejsca zajęły AT\&T (telefonia, internet - 123,8 mld USD), Hewlett-Packard (informatyka, komputery, aparatura elektroniczna - 118,7 mld USD), Nippon Telegraph and Telephone (telefonia, internet - 107 mld USD). Jeżeli chodzi jednak o samą branżę komputerową to IBM zajął 2 pozycję zaraz po HP, a przed Samsungiem (www.businessweek.com).

Analizując wartości zysków i strat IBM również zajął 4 miejsce, ale w swojej branży drugie z wynikiem 12,3 mln USD, zaraz po Microsoft - 16 mln USD, a przed HP - 8 mln USD. W ostatnich latach istotnie zmieniła się sytuacja zróżnicowania wartości rynkowej korporacji. W 2008 roku pierwsze miejsce zajął Microsoft (253,2 mld USD), drugie IBM (150,5), trzecie Google (149). W 2011 roku IBM, po raz pierwszy od 1996 roku, wyprzedził Microsoft, który został wyceniony na 214 mld USD, a rywal na 213. Firma Microsoft natomiast oddała pozycję lidera swojemu największemu konkurentowi - koncernowi Apple 
(362 mld USD) (Gazeta Wyborcza). Takie zachowanie rynku jest z jednej strony efektem niewielkiego zakresu produktów i usług oraz znakomitego marketingu na rynku konsumenckim (Apple) jak i znacznej dywersyfikacji rodzajów działalności i poszukiwania nowych zakresów działań na rynkach biznesowych (IBM).

Rozpatrując wielkość posiadanych aktywów w 2010 roku najlepszą pozycję zajmuje Sony $(157,5$ mld USD), następnie HP $(124,5)$ i IBM $(99,9)$ (http://www.stock-analysis-on. net/NYSE/Company). Taka pozycja ułatwia zapewne podejmowanie strategicznych decyzji i zwiększa możliwości rozwojowe. Nie jest to jednak pozycja łatwa do utrzymania. Świadczy o tym choćby poważne zachwianie pozycji HP po ogłoszeniu jesienią 2011 roku zaprzestania rozwoju sprzętu (tablety, zaawansowane telefony komórkowe tzw. smartfony) pracującego pod kontrolą sytemu operacyjnego webOS (opracowanego przez niegdysiejszego lidera firmę Palm).

Duży stopień zróżnicowania ekonomicznego korporacji informatycznych potwierdza wskaźnik syntetyczny potencjału ekonomicznego, obliczony w oparciu o mierniki: wartość sprzedaży, aktywów, wartość rynkową. Najwyższą wartość tego miernika osiągnął IBM - 5,2, a zaraz po nim Microsoft - 4,7 i HP - 4,5 (Kilar 2009). Tylko w przypadku IBM na potencjał firmy poszczególne mierniki empiryczne wpływały, w zbliżony sposób, gdyż dla Microsoft potencjał uzależniony jest od wartości rynkowej, a dla HP ważna jest wartość sprzedaży (tab. 2).

Tab. 2. Wartości miernika syntetycznego i jego struktura

\begin{tabular}{|l|c|c|c|c|}
\hline \multirow{2}{*}{ Korporacja } & \multirow{2}{*}{ Miernik } & \multicolumn{3}{|c|}{ Struktura miernika } \\
\cline { 3 - 5 } & & \multicolumn{3}{|c|}{ udział \% wartości } \\
\cline { 3 - 5 } & & sprzedaży & aktywów & rynkowej \\
\hline IBM & 5,2 & 31,2 & 36,5 & 32,2 \\
\hline Microsoft & 4,7 & 20,2 & 22,6 & 57,2 \\
\hline HP & 4,5 & 39,6 & 31,3 & 29,1 \\
\hline Samsung & 3,9 & 39,6 & 36 & 24,4 \\
\hline Nokia & 3,6 & 34 & 23 & 43 \\
\hline
\end{tabular}

Źródło: opracowanie własne na podstawie Kilar 2009

IBM nie tylko przoduje w rankingach dotyczących potencjału ekonomicznego, ale także innowacyjności. W 2010 roku naukowcy IBM zarejestrowali 5896 patentów (tab. 3), tym samym koncern po raz 18 z rzędu znalazł się na szczycie najbardziej innowacyjnych firm na świecie. Stąd też troska IBM o poziom innowacyjności w firmach, ponieważ sami sprzedają usługi konsultingowe usprawniające ten obszar działalności firm.

Wśród zarejestrowanych w 2010 roku patentów znalazły się między innymi: metody gromadzenia, analizy oraz przetwarzania danych pochodzących z wielu źródeł na temat pacjentów w celu zwiększenia skuteczności diagnostyki medycznej; systemy przewidywania stanu nasilenia ruchu drogowego w oparciu o informacje uzyskiwane drogą radiową; techniki analizy danych z czujników umieszczonych na twardych dyskach w celu zapewnienia 
szybszej reakcji w sytuacjach awaryjnych na wypadek trzęsień ziemi i innych klęsk żywiołowych; oraz technologia umożliwiająca komunikację w oparciu o układy elektroniczne wykorzystujące impulsy świetlne zamiast sygnałów elektrycznych, co zwiększa wydajność systemów obliczeniowych.

Tab. 3. Liczba zarejestrowanych patentów w latach 2009 i 2010

\begin{tabular}{|l|c|c|}
\hline \multicolumn{1}{|c|}{ Firma } & 2010 rok & 2009 rok \\
\hline IBM & 5896 & 4914 \\
\hline Samsung & 4551 & 3515 \\
\hline Microsoft & 3094 & 2906 \\
\hline Cannon & 2552 & 2206 \\
\hline Panasonic & 2482 & 1829 \\
\hline
\end{tabular}

Źródło: opracowanie własne na podstawie www.ibm.com

Od wielu lat IBM jest również jedną z najbardziej rozpoznawalnych marek na świecie, zaraz po Coca-Coli i Microsoft, a od 2008 roku prześcignął nawet swojego konkurenta (raport Best Global Brands). Z kolei według zestawienia „Forbesa” w 2011 r. IBM zajmuje 31 miejsce wśród największych firm na świecie (http://www.forbes.com).

\section{NOWE WYZWANIA}

Od blisko wieku IBM prowadzi badania, aby odkryć nowe możliwości rozwoju oraz przewidzieć nadchodzące wyzwania. W wyniku tych działań chce opracować takie rozwiązania, które mogą zmienić funkcjonowanie świata. IBM wprowadzając konsekwentnie nowe pomysły technologiczne próbuje zaadaptować je do skali światowej. Dzisiaj nie wystarczy skala firmy, korporacji czy gałęzi biznesu.

Jednym z pomysłów jest szereg innowacji, które mają odmienić oblicze miast w ciągu następnych lat. Można tu wskazać różne przykłady zainteresowań koncernu poczynając od opieki zdrowotnej i służb porządkowych do gospodarki wodnej, energetycznej i komunikacji miejskiej. W celu racjonalizacji i usprawnienia funkcjonowania tych systemów - muszą się one stać mądrzejsze. Oznacza to zazwyczaj ułatwienie dostępu do informacji, większą automatyzację standardowych działań jak i wspomaganie decyzji wymagających planowania i bezpośredniej interwencji specjalistów.

\section{Miasta i opieka zdrowotna}

Wysoka gęstość zaludnienia w miastach niesie ze sobą wymierne korzyści ale i wiele zagrożeń. Jednym z nich jest niewątpliwie zagrożenie epidemiologiczne. Dzięki testowanym dziś rozwiązaniom urzędnicy odpowiedzialni za opiekę zdrowotną będą mogli w przyszłości dokładnie wiedzieć kiedy, gdzie i w jaki sposób dana choroba się rozprzestrzenia - a nawet, 
które dzielnice zostaną zaatakowane w następnej kolejności. Naukowcy wyposażą urzędników miejskich, szpitale, szkoły i zakłady pracy w narzędzia, które pomogą skuteczniej wykrywać i śledzić infekcje takie, jak wirus H1N1 czy grypy sezonowej, przygotować się na ich nadejście, a nawet zapobiegać ich rozwojowi. IBM już dziś współpracuje z organizacjami na całym świecie takimi, jak należąca do pozarządowej organizacji Nuclear Threat Initiative (NTI) jednostka Global Health and Security Initiative oraz organizacja monitorująca choroby zakaźne Middle East Consortium on Infectious Disease Surveillance (MECIDS), na rzecz standaryzacji metod współużytkowania danych o zdrowiu pacjentów i analizowania epidemii chorób zakaźnych. Standardy ochrony danych osobowych w Stanach Zjednoczonych są odmienne od rozwiązań przyjętych w innych regionach świata (np. w Europie). Pozostaje mieć nadzieję, że wdrażane przez amerykański koncern rozwiązania będą mogły być zastosowane z korzyścią dla zdrowia mieszkańców miast również poza Stanami bez narażenia na szwank ich prywatności.

\section{„Inteligentne" budynki}

Przy rekordowej liczbie osób zamieszkujących pojedyncze budynki w miastach, obiekty mają być mądrzej budowane. Dziś wiele układów wchodzących w skład budynków - ogrzewanie, kanalizacja, odprowadzanie ścieków, elektryczność - jest zarządzanych oddzielnie. W przyszłości technologia odpowiedzialna za zarządzanie usługami komunalnymi będzie działać niczym żywy organizm, który odbiera różne bodźce i szybko na nie reaguje. Ochrona mieszkańców, oszczędzanie zasobów i zmniejszanie negatywnego wpływu na środowisko powinno odbywać się przy równoczesnym dbaniu o poziom życia. Tysiące czujników zainstalowanych w budynkach będzie monitorować wszystko wokół, od ruchu i temperatury, do poziomu wilgotności, liczby osób aktualnie przebywających w budynku i naturalnego oświetlenia. Dzięki temu systemowi będzie można przeprowadzić odpowiednie interwencje zanim coś się zepsuje, służby szybkiego reagowania będą w stanie natychmiast przystąpić do działania dostosowując konieczne zasoby, a osoby użytkujące lokale mieszkalne i biurowe będą mogły monitorować swoje zużycie energii i emisję dwutlenku węgla w czasie rzeczywistym a co za tym idzie - podejmować odpowiednie kroki w celu redukcji tych wskaźników. W niektórych budynkach już dziś wykorzystywane są inteligentne rozwiązania w celu zmniejszenia zużycia energii, poprawy wydajności jej wykorzystania oraz zwiększenia komfortu i bezpieczeństwa lokatorów. Przykładem może być chiński hotel Dragon Hotel, który zlecił IBM stworzenie zaawansowanego, wewnętrznie połączonego systemu zarządzającego budynku w ramach inicjatywy przekształcenia hotelu w „Mądrzejszy Hotel”. Na mocy zawartej umowy IBM przeprowadzi integrację głównych systemów tam działających.

\section{Miasta i pojazdy elektryczne}

Jednym z największych zagrożeń zdrowotnych obecnych w miastach jest emisja hałasu i spalin emitowanych przez transport (głównie z silników spalinowych). Obecnie w elektryfikacji upatruje się rozwiązania tego podstawowego problemu miast. Jednak poziom rozwoju infrastruktury wspierającej transport oparty na silnikach spalinowych (m.in. ropociągi, rafinerie, stacje paliw) oraz wciąż niezadowalająca wydajność rozwiązań alternatywnych zdają się wyraźnie hamować potrzebne zmiany. Prace naukowców IBM idą w kierunku wyposa- 
żenia pojazdów elektrycznych w akumulatory nowej generacji, którym jedno naładowanie wystarczy na wiele dni, a nawet miesięcy w zależności od częstotliwości jazdy samochodem. Naukowcy i partnerzy IBM pracują nad stworzeniem nowych akumulatorów, które umożliwią samochodom z napędem elektrycznym przebycie od 500 do $800 \mathrm{~km}$ po jednym naładowaniu. Obecnie te samochody po jednorazowym naładowaniu akumulatora mogą przejechać od 80 do $150 \mathrm{~km}$. Ponadto stworzona zostanie mądrzejsza sieć miejska umożliwiająca ładowanie samochodów w miejscach publicznych oraz wykorzystywanie do ładowania odnawialnych źródeł energii takich jak wiatr, aby pojazdy z założenia ekologiczne nie musiały zużywać energii wytwarzanej w elektrowniach opalanych np. węglem. Doprowadzi to do redukcji emisji spalin oraz zmniejszenia hałasu ulicznego. IBM wspólnie z duńską organizacją badawczą EDISON pracuje nad stworzeniem inteligentnej infrastruktury, która umożliwi dostosowanie miast do masowego przejścia na pojazdy z napędem elektrycznym zasilane przez energię odnawialną.

\section{Miasto, woda i energia}

Infrastruktura miejska, szczególnie w Europie, funkcjonuje dziś na zasadach i w ramach ustalonych bardzo często jeszcze w okresie rewolucji przemysłowej. Rozwiązania będące rewolucyjnymi w XIX wieku, dziś mogą się nie sprawdzać w obsłudze wielokrotnie większych ośrodków miejskich. Jednym z niezwykle ważnych problemów hamujących rozwój miast jest obecnie woda. IBM przewiduje, że w miastach będą montowane mądrzejsze układy kanalizacyjno-wodociągowe, dzięki czemu ilość marnowanej wody zostanie zmniejszona aż o 50\%. Dodatkowo instalowane będą również mądrzejsze systemy odprowadzania ścieków, które nie tylko będą zapobiegać wyciekaniu zanieczyszczeń do rzek i jezior, ale będą również oczyszczać wodę i uzyskiwać w ten sposób bezpieczną wodę pitną. Wykorzystanie zaawansowanych technologii oczyszczania wody umożliwi miastom przeprowadzanie lokalnego przetwarzania wtórnego i ponownego wykorzystywania wody, przyczyniając się do zredukowania energii potrzebnej do transportu wody aż o $20 \%$. Interaktywne liczniki i czujniki zostaną zintegrowane z systemami wodociągowymi i energetycznymi, zapewniając w czasie rzeczywistym precyzyjne dane na temat zużycia wody.

\section{Miasto i bezpieczeństwo publiczne}

Władze miast będą w stanie zmniejszyć liczbę sytuacji kryzysowych, takich jak zdarzenia przestępcze czy katastrofy naturalne, a nawet zapobiegać ich występowaniu. IBM już teraz pomaga przedstawicielom organów ścigania w analizowaniu informacji w odpowiednim czasie, tak aby służby bezpieczeństwa mogły podejmować proaktywne działania i zareagować czasami jeszcze przed złamaniem prawa. Przykładowo zarządzający strażą pożarną w Nowym Jorku wyznaczyli IBM zadanie stworzenia najnowocześniejszego systemu do gromadzenia i współużytkowania danych w czasie rzeczywistym - celem jest zapobieganie potencjalnym pożarom i jednoczesna ochrona strażaków i służb ratunkowych.

Specjaliści IBM jednocześnie projektują inteligentne systemy wałów przeciwpowodziowych, aby uchronić miasta przed niszczycielską siłą wody (www.ibm.com).

Poza nowymi pomysłami dla miast IBM ogłosił piątą edycję listy „Next 5 in 5”, czyli pięciu innowacji, które zmienią styl życia i pracy ludzi w ciągu najbliższych pięciu lat. 
Najważniejsze wynalazki mają zmienić: hologramy, akumulatory, transport indywidualny, komputerowe centra przetwarzania danych.

\section{Hologramy}

Naukowcy z IBM Research rozpoczęli prace nad nowymi sposobami wizualizacji danych 3-D, technologii, która umożliwi inżynierom wniknięcie do wnętrz różnego rodzaju projektów - począwszy od budynków a kończąc na oprogramowaniu. Może to się odbywać np. poprzez tworzenie symulacji rozprzestrzeniania się chorób w interaktywnym świecie 3-D i wizualizując trendy zachodzące na całym świecie za pośrednictwem Twittera - wszystko w czasie rzeczywistym z niewielkimi odchyleniami lub pozbawione takich odchyleń.

\section{Tlen w bateriach}

W ciągu najbliższych pięciu lat, postęp naukowy w elektronice i wydajności akumulatorów przedłuży dziesięciokrotnie zdolność funkcjonowania urządzeń zasilanych bateryjnie. Wiele firm i instytutów naukowych pracuje nad zastąpieniem ciężkiej litowo-jonowej baterii obecnie powszechnie używanej. Naukowcy z IBM pracują m.in. nad bateriami, które wykorzystają powietrze, którym oddychamy do procesu reakcji z metalem o dużej gęstości energii eliminując kluczowy czynnik hamujący stworzenie baterii o dłuższej wytrzymałości. Jeśli badania się powiodą, stworzony zostanie lekki akumulatorek o dużej mocy przystosowany do zasilania szerokiego spektrum urządzeń - od elektrycznych samochodów do urządzeń elektronicznych.

Analizując podstawowy moduł konstrukcyjny urządzeń elektronicznych - tranzystor IBM stawia sobie za cel zredukowanie energii czerpanej przez tranzystor do mniej niż 0,5 V. Zastosowanie niskonapięciowych tranzystorów ma znacznie zmniejszyć zapotrzebowanie na energię elektryczną co być może umożliwi nawet pozbycie się baterii w niektórych urządzeniach jak telefony komórkowe lub czytniki elektroniczne.

\section{Transport spersonalizowany}

W ciągu następnych pięciu lat, zaawansowana technologia analityczna zapewni uzyskanie spersonalizowanych rekomendacji, które znacznie skrócą czas dojazdu do celu (np. do pracy). Systemy adaptacyjne ruchu drogowego będą intuicyjnie przyswajały wzorce podróżowania i zachowania osób, aby zwiększyć bezpieczeństwo podróży i wyznaczyć szybszą trasę. Naukowcy IBM tworzą obecnie nowe modele do przewidywania skuteczności różnych tras przejazdu w celu dostarczenia informacji, które wykraczają poza tradycyjne raporty drogowe, urządzenia, które jedynie wskazują aktualne miejsce i aplikacje oparte na sieci, które obliczają szacowany czas podróży.

\section{Centra przetwarzania danych na nowo}

Innowacje w dziedzinie komputerów i centrów danych umożliwią wykorzystanie nadwyżki ciepła i energii generowanej przez pracujące tam urządzenia do ogrzewania budynków zimą i zasilania klimatyzacji latem. Do 50\% energii wykorzystywanej przez nowoczesne centra danych przeznaczane jest obecnie na chłodzenie urządzeń. Większość ciepła jest mar- 
nowana, ponieważ ulatnia się do atmosfery. Nowe technologie, takie jak nowoczesne chipowe systemy chłodzenia wodą, stworzone przez IBM, umożliwiają ponowne wykorzystanie energii cieplnej z klastra komputerowego np. do podgrzewania wody w biurach i w domach.

Pilotażowy projekt prowadzony w Szwajcarii wykorzystuje system komputerowy wyposażony w taką technologię. Ma on zaoszczędzić do 30 ton emisji dwutlenku węgla rocznie, co jest równe 85 procentom redukcji tzw. śladu węglowego. Nowatorska sieć mikrostrumieniowych modułów wewnątrz radiatora jest przyczepiona do powierzchni każdego chipa w klasterze komputerowym, co umożliwia pompowanie wody wewnątrz mikronów półprzewodników. Przepływ wody blisko każdego chipa umożliwia bardziej skuteczne schładzanie. Woda podgrzana do $60^{\circ} \mathrm{C}$ jest następnie przepompowywana poprzez wymiennik ciepła w celu skierowania ciepła w inne miejsce (www.gazeta.pl).

Jest wiele innych inicjatyw IBM, które świadczą o woli przewodzenia tej firmy w innowacyjności. Obecnie IBM ogłosił, że w 2019 roku będzie miał superkomputer, który dorówna potędze ludzkiego mózgu. Na chwilę obecną BlueGena symuluje już 4,5\% aktywności mózgu człowieka. Obecnie stworzone prototypy procesorów oparte są na krzemie i mają do 262 tys. synaps. W przyszłości IBM chce stworzyć jednocentymetrowy chip będący odpowiednikiem miliona neuronów i 10 mld synaps. Projekt finansuje amerykańska rządowa agencja wojskowa DARPA (całość ma kosztować $41 \mathrm{mln}$ USD), jednak IBM przedstawił również możliwe cywilne zastosowanie nowych komputerów. Poprzez jednoczesną analizę różnorodnych danych dotyczących temperatury, ciśnienia, wysokości fal i poziomu wód komputer taki mógłby precyzyjnie przewidywać nadejście fal tsunami. Innym zastosowaniem nowych komputerów proponowanym przez inżynierów IBM jest elastycznie dostosowywane regulowanie ruchu ulicznego. W projekt SyNAPSE zaangażowane są także cztery amerykańskie uczelnie wyższe: Columbia University, Cornell University, University of California-Merced i University of Wisconsin-Madison (http://wyborcza.biz).

IBM nie tylko tworzy nowe innowacyjne rozwiązania, ale także stworzył narzędzie - Innovation Assessment Tool, dostępne on-line, które ma mierzyć poziom innowacyjności w firmach. IBM przebadał tym testem ponad 750 prezesów największych firm, a test pozwala na porównanie uzyskanych wyników do tych uzyskanych przez owe 750 firm. Ocenie poddawane są 4 obszary działalności: plan innowacji w firmie, przewodzenie innowacji i kulturze innowacyjności, współpracy i partnerstwu firm na rzecz innowacji, biznesowi i technologii (inngenerator.pl).

Warto zaznaczyć, że IBM aktywnie działa również na polskim rynku. Firma IBM była m.in. Partnerem Technologicznym w inicjatywie: „Krajowi Liderzy Innowacji i Rozwoju”. Konkurs adresowany był do firm, gmin oraz organizacji i innych podmiotów gospodarczych. Składał się z dwóch edycji: regionalnej przeprowadzanej w 16 województwach oraz ogólnopolskiej. Nagrodzone zostały projekty i programy, które wyróżniały się szczególną innowacyjnością w jednej z poniższych kategorii: wizjoner IT, innowacyjna bądź dynamicznie rozwijająca się firma, innowacyjny produkt, innowacyjny projekt unijny, innowacyjna usługa, gmina oraz organizacja. 


\section{OSKARŻENIA IBM}

Pomimo, że IBM zajmuje czołową pozycję na rynku międzynarodowym to w długiej historii firmy nie zabrakło wydarzeń rzutujących na jej dobre imię.

W 2003 roku grupa SCO oskarżyła IBM o ujawnianie tajemnic handlowych związanych z systemem UNIX poprzez udostępnianie części kodu społeczności OpenSource. IBM zakupił w 1985 roku licencję na produkowanie własnej odmiany systemu UNIX (AIX) od firmy AT\&T, która system ten pierwotnie stworzyła i wówczas posiadała do niego wszelkie prawa. W 1995 roku prawa te odkupiła właśnie firma SCO, która tym samym stała się posiadaczem praw intelektualnych systemu UNIX. Nowe pozwy SCO dotyczyły domniemanego złamania przez IBM postanowień umowy licencyjnej zawartej między firmami poprzez opracowanie i sprzedaż pochodnych Unixa - systemów IBM AIX i IBM Dynix - już po wygaśnięciu unieważnionej przez SCO licencji. Nowe zarzuty zwiększyły wysokość odszkodowania - jakiego SCO domaga się od IBM - do 5 mld USD (http://www.computerworld.pl/artykuly).

W 2008 roku Korporacja IBM dostała czasowy zakaz zawierania kontraktów z amerykańskimi agencjami federalnymi, w związku z kontraktem z Agencją Ochrony Środowiska (EPA). Zakaz na firmę nałożył sąd ze stanu Virginia, po znalezieniu niejasności w dokumentacji kontraktu między IBM a Agencją Ochrony Środowiska (http://wiadomosci.gazeta.pl).

W 2011 roku Komisja Europejska rozpoczęła postępowanie wyjaśniające względem działań firmy IBM. Pojawiły się bowiem skargi konkurentów sugerujące nadużywanie pozycji dominującej na europejskim rynku komputerów mainframe, co byłoby niezgodne z unijnym prawem. Według konkurentów IBM w sposób nielegalny wiązał sprzedawany przez siebie sprzęt do komputerów mainframe z systemem operacyjnym dla tych urządzeń. International Business Machines Corporation zobowiązał się do zapewnienia określonych części zamiennych, a także informacji technicznych na rozsądnych i niedyskryminujących warunkach przez okres pięciu lat (http://di.com.pl/news).

Również firma IBM oskarżyła firmę Amazon, specjalizującą się w sprzedaży elektronicznej, o pogwałcenie prawa patentowego. Oskarżenie dotyczyło pięciokrotnego naruszenia prawa patentowego dotyczącego zasad reklamy i sprzedaży produktów (http://www.firma. egospodarka.pl).

\section{IBM KRAKÓW}

IBM BTO (Business Transformation Outsourcing) powstało w Krakowie w 2002 roku. To międzynarodowe centrum biznesowo-outsourcingowe jest znakomitym przykładem charakteryzującym lokalne i globalne działania koncernu. Stanowi obecnie (grudzień 2011 r.) miejsce zatrudnienia dla ponad 1200 świetnie wykształconych pracowników mówiących w sumie w 30 różnych językach. Dzięki swej specjalistycznej wiedzy i doświadczeniu dostarczają oni szerokiego wachlarza usług głównie z zakresu księgowości i zobowiązań finansowych. Wśród nich jest także 72 obcokrajowców z 21 krajów całego świata. Oddział obsługuje kilkanaście krajów i odpowiedzialny jest za współpracę z wieloma klientami światowymi, oferując im nie tylko unikalne rozwiązania, ale przede wszystkim wiedzę i wieloletnie doświadczenie. 
Obecnie klientami IBM BTO jest 14 koncernów z całej Europy z następujących branż: chemiczno-paliwowa, sprzętu medycznego, elektronika użytkowa, motoryzacja, chemiczno-gumowa, usług internetowych, produktów dla sektora odzieżowego, usług rekrutacyjnych, spożywcza, sektor FMCG, zarządzanie dokumentami i informacją, chemiczno-gazowa, sektor produktów dla gospodarstwa domowego. Na poszczególnych kontraktach pracuje od 20 do 300 osób, w zależności od ilości przejętych obowiązków. Dodatkowo IBM BTO współpracuje z innymi centrami, które są w Sofii, Bangalore, Delhi, Buenos Aires i Manili, Dublinie i Houston, co pozwala na efektywne dzielenie i przenoszenie różnych zadań do innych ośrodków. Efektywność pracy zwiększa także mobilność pracowników, którzy poza wyjazdami zagranicznymi mają możliwość pracy poza biurem od 1 do 3 dni, z czego korzysta już około $1 / 5$ zatrudnionych.

W roku 2007 w niemieckim opiniotwórczym czasopiśmie „Der Spiegel” ukazał się artykuł pod wiele mówiącym tytułem „As Good as Bangalore. Why Krakow Still Works for IBM” (Der Spiegel 26 IX 2007). „Tak dobry jak Bangalore” - porównanie do jednego z największych i najważniejszych centrów outsourcingowych na świecie dobrze świadczy o pozycji krakowskiego IBM BTO.

Obok centrum biznesowo-outsourcingowego w Krakowie funkcjonuje jeszcze laboratorium oprogramowania IBM. Jest ono jedną z 40 placówek programistycznych koncernu na świecie i pierwszą, która powstała w tej części Europy. Zajmuje się projektowaniem i wdrażaniem oprogramowania. Ośrodek dostarcza też usługi lokalnym firmom w Polsce, oferując wsparcie przy wdrażaniu zaawansowanego oprogramowania. Początki jego działalności sięgają 2005 roku. Początkowo zatrudniano 40 pracowników, a obecnie jest to ponad 300 osób. IBM jest drugim na świecie największym producentem oprogramowania a do jego marek należą: Tivoli, WebSphere, Lotus, Rational, DB2.

IBM stara się mieć także swój wpływ na jakość kształcenia w miastach, w których ma siedziby. W Krakowie w Uniwersytecie Pedagogicznym na mocy porozumienia z IBM i Capgemini uruchomiono studia II stopnia na kierunku filologia romańska, specjalność przetwarzanie informatyczne i lingwistyczne dokumentów pisemnych. Oba przedsiębiorstwa przygotowują studentów do pracy poprzez wspólną realizację programu nauczania oraz umożliwiają odbycie obowiązkowej 6-miesięcznej praktyki zawodowej.

\section{Podsumowanie}

W świetle przedstawionych osiągnięć IBM słuszna wydaje się być wizja firmy - „sukces klienta naszym sukcesem, innowacyjność dla nas i całego świata”. IBM nie ogranicza się w zakresie innowacyjności tylko do swojej branży, ale dokłada wszelkich starań, aby proponowane rozwiązania przyniosły korzyści jak największej liczbie odbiorców. Ponadto chętnie dzieli się swoimi doświadczeniami (co pokazał przykład platformy IBM PC), biorąc udział w różnych inicjatywach wspomagających inne firmy oraz współpracując z wieloma uczelniami wyższymi. Ogromny potencjał ekonomiczny i bardzo silna pozycja na rynku światowym potęgują możliwości w zakresie rozwoju innowacji. Wysokie miejsca w międzynarodowych rankingach potwierdzają, że IBM mimo swojego wieku nie zamierza spocząć na laurach i cały czas szuka nowych sposobów rozwoju. 


\section{Literatura}

Bal-Woźniak T., 2009, Infrastruktura systemu innowacyjnego jako czynnik transformacji struktur przemystowych, [w:] Wpływ procesów globalizacji i integracji europejskiej na transformacje struktur przemysłowych, red. Z. Zioło, T. Rachwał, Prace Komisji Geografii Przemysłu Polskiego Towarzystwa Geograficznego, nr 12, Warszawa-Kraków, s. 45-57.

Borowiec M., Dorocki S., Jenner B., 2009, Wpływ zasobów kapitalu ludzkiego w ksztaltowanie społeczeństwa informacyjnego i innowacyjności struktur przemysłowych, [w:] Z. Zioło, T. Rachwał (red.), Funkcje przemystu w ksztaltowaniu spoteczeństwa informacyjnego, Prace Komisji Geografii Przemysłu Polskiego Towarzystwa Geograficznego, nr 13, Warszawa-Kraków, s. 95-109.

Gierańczyk W., 2009, Innowacyjność jako główny filar społeczeństwa informacyjnego Europy, [w:] Z. Zioło, T. Rachwał (red.), Wpływ procesów globalizacji i integracji europejskiej na transformacje struktur przemysłowych, Prace Komisji Geografii Przemysłu Polskiego Towarzystwa Geograficznego, nr 12, Warszawa-Kraków, s. 82-94.

Grad N., 2007, Sytuacja polskiej Gospodarki Opartej na Wiedzy na tle innych krajów Unii Europejskiej, [w:] Europa Młodzieży - Młodzież Europie, Wyd. TIAL, Łódź, s. 9-16.

Kilar W., 2009, Rola korporacji Apple w kształtowaniu społeczeństwa informacyjnego, [w:] Z. Zioło, T. Rachwał (red.), Rola przedsiębiorczości w ksztaltowaniu społeczeństwa informacyjnego, Przedsiębiorczość-Edukacja, nr 5, Warszawa-Kraków, s. 48-57.

Kilar W., 2009, Zróżnicowanie potencjału ekonomicznego światowych korporacji informatycznych, [w:] Z. Zioło, T. Rachwał (red.), Funkcje przemystu w ksztattowaniu społeczeństwa informacyjnego, Prace Komisji Geografii Przemysłu Polskiego Towarzystwa Geograficznego, nr 13, Warszawa-Kraków, s. 110-121.

Kukliński A. (red.), 2001, Gospodarka oparta na wiedzy. Wyzwania dla Polski XXI wieku, Komitet Badań Naukowych, Warszawa.

Zioło Z., 2006, Zróżnicowanie światowej przestrzeni przemysłowej w świetle koncentracji siedzib zarządów wiodących korporacji, [w:] Z. Zioło, T. Rachwał (red.), Międzynarodowe uwarunkowania rozwoju przemystu, Prace Komisji Geografii Przemysłu Polskiego Towarzystwa Geograficznego, nr 8, Warszawa-Kraków, s. 9-26.

Zioło Z., 2009, Procesy ksztaltowania się światowych korporacji i ich wptyw na otoczenie, [w:] Z. Zioło, T. Rachwał (red.), Wpływ procesów globalizacji i integracji europejskiej na transformacje struktur przemysłowych, Prace Komisji Geografii Przemysłu Polskiego Towarzystwa Geograficznego, nr 12, Warszawa-Kraków, s. 11-31.

\section{Strony internetowe}

ftp://public.dhe.ibm.com /annualreport/2010/2010_ibm_annual.pdf - roczny raport finansowy IBM http://www.businessweek.com/interactive_reports\%20/it100_2009.html

http://www.stock-analysis-on.net/NYSE/Company

http://komputerwfirmie.gazeta.pl

http://www.interbrand.com/en/best-global-brands - raport Best Global Brands

http://www.ibm.com/

http://wyborcza.biz/

http://www.forbes.com/global2000/list/

http://www.computerworld.pl/artykuly

http://wiadomosci.gazeta.pl

http://di.com.pl/news

http://www.firma.egospodarka.pl 


\section{IBM - International Business Innovations}

Innovation seen as the development of new methods, tools, new approaches and improvement of the existing processes is generally synonymous with "young" and modern companies. Hardly anyone would expect after 100 years of a company's existence that it is able to continually meet the highest standards of business and compete on the international market, especially in terms of innovation. An example of such a company is International Business Machines (IBM). The company was founded in 1911 and initially dealt with the production of various equipment: weights, meat slicers, or data storage media, such as punch cards and machines for them. The latter have become over time the most important activity of the corporation. At the turn of the 1960s, IBM introduced hard disk drives, developed the world's first storage, and introduced to customers the software language Fortran, which is still in use. In 1969, IBM computers were used by NASA during the first man on the moon mission. In 1981, the company created the first personal computer IBM 5150 PC, which the weekly magazine "Time" dubbed "machine of the year". Thanks to its innovations, regardless of the era, IBM has always been ahead of the reality in which it is located. Today IBM announced that in 2019 it will have a supercomputer, which should come close to matching the power of the human brain. At the moment, BlueGene already copies $4.5 \%$ of human brain activity. The activities of such a powerful company are not only associated with market developments. In the 1990s, the company began to focus on new market areas, in particular services. In November this year, IBM introduced the five innovations that over the next five years would significantly improve the quality of life of urban citizens around the world, as well as reduce potential hazards. Therefore, the vision of the company seems to be right - our customer's success, innovation for us and the world. The purpose of this paper is to present innovative solutions implemented by IBM in terms of technology and services.

Dr Radosław Uliszak

Uniwersytet Pedagogiczny, Kraków

Instytut Geografii

Zakład Geografii Społeczno-Ekonomicznej UP

e-mail: ulira@up.krakow.pl

Mgr Nina Grad

Uniwersytet Jagielloński

Instytut Geografii i Gospodarki Przestrzennej

Zakład Geografii Ludności, Osadnictwa i Rolnictwa

e-mail: ninagrad@interia.pl 